\title{
Dimensions of Movement
}

From features to remnants

Edited by

Offprint

Artemis Alexiadou

Elena Anagnostopoulou

Sjef Barbiers

Hans-Martin Gaertner 


\title{
Chapter 7
}

\section{Remnant movement and partial deletion}

\author{
Roland Hinterhölzl \\ Humboldt University
}

\section{Introduction}

The term remnant movement was coined by den Besten and Webelhuth (1987) to account for a peculiarity of verb-preposing in German and Dutch. Provided that only XPs can move into XP-positions, it follows that what has been moved into [SpecCP] in (1) is not simply a verb, but must be minimally a full VP. Thus, they propose to analyse (1a) parallel to cases of VP-preposing (cf. (2a)), in which the direct object has been scrambled out prior to VP-to-CP movement. The moved VP is called a remnant category since it contains, at least, the trace of the direct object as is indicated in (2b).

This is an offprint from:

Artemis Alexiadou, Elena Anagnostopoulou, Sjef Barbiers and Hans-Martin Gärtner (eds.)

Dimensions of Movement

John Benjamins Publishing Company

Amsterdam/Philadelphia 2002

Published as Vol. 48 of the series

LINGUISTIK AKTUELL / LINGUISTICS TODAY,

Series editor: Werner Abraham, ISSN 0166-0829

ISBN 9027227691 (Eur) / 1588111857 (US)

(C) 2002 - John Benjamins B.V.

No part of this book may be reproduced in any form,

by print, photoprint, microfilm or any other means, without written permission from the publisher.
(1) a. Gelesen hat Hans das Buch. read-PART has Hans the book 'Hans has read the book.'

b. Lieben will Hans die Maria. love-INF wants Hans the Maria 'Hans wants to love Maria.'

(2) a. [vp das Buch gelesen] hat Hans $t_{\mathrm{vP}}$

b. $\left[\mathrm{vP}_{\mathrm{SCR}} \text { gelesen] hat Hans [das Buch }\right]_{\mathrm{SCR}}$

However, there is an analysis of verb-preposing that can do without remnant movement. Given that movement is copy-and-delete (Chomsky 1993, 1995), (1a) can be analyzed in terms of partial deletion (Wilder 1995; Hinterhölzl 1997; Ćavar and Fanselow (C\&F) 1998). C\&F argue convincingly that cases of discontinuous NPs as illustrated in (3a) should be handled in terms of movement (rather than in terms of base-generation) employing selective deletion operations as indicated in (3b). 
(3) a. Englische Bücher hat er keine gekauft. English books has he none bought 'He has bought no English books.'

b. [keine englische Bücher] hat er [keine Büreker] gekauft.

Given the availability of both remnant movement and partial deletion, two questions arise: 1. Can specific cases of incomplete category dislocation be better explained in terms of conditions on movement or in terms of conditions on deletion. In other words, should (2) be reanalyzed as is illustrated in $\left.\left(2^{\prime}\right)\right) ?$

$\left(2^{\prime}\right)$ a. [das Buch gelesen] hat Hans Has Buthelesen].

b. [as Butesen] hat Hans [das Buch gelesen.

2. Since both operations yield similar results, should the grammar allow for both remnant movement and partial deletion to occur? With respect to the first question, we will look at cases with contradictory constituent requirements which show up in restructuring contexts and are illustrated in (4) and (5). In (4a), the dependent infinitive together with its CP-complement has been fronted. However, embedded infinitive and the CP-complement do not form a constituent after verb-complex formation took place, as is illustrated in $(4 b-c)$. (5a) indicates that the embedded infinitive and its direct object seem to form a constituent (excluding the modal verb), while (5b) indicates that the embedded infinitive and the modal form a constituent which can be fronted without the embedded argument.

(4) a. [fragen ob wir zustimmen] wird er wohl müssen. ask whether we agree will he well must 'He will probably have to ask whether we agree.'

b. ${ }^{\star}$ Er wird wohl [fragen ob wir zustimmen] müssen.

c. Er wird wohl [fragen] müssen [ob wir zustimmen].

(5) a. [ein Haus bauen] wird er wollen. a house build-INF will he want 'He will want to buy a house.'

b. [bauen wollen] wird er ein Haus. build want will he a house

c. Er wird [ein Haus [bauen wollen]].

Since the constituent structure after verb-complex formation is as given in $(5 c)$, both (4a) and (5a) could be handled in a parallel and simple fashion in terms of partial deletion as is illustrated in (6). However, we will argue that these cases should not be treated in terms of partial deletion but call for an analysis that employs remnant movement.

(6) a. [fragen ob wir zustimmen] wird er wohl [üssen wir zustimmen]

b. [ein Haus bauen when wird er [ein Hatts watlen].

With respect to the second question, we will argue that the two operations can coexist since they have a complementary distribution in the grammar: partial deletion results from pied-piping (and additional constraints), while remnant movement results from the unavailability of pied-piping

The chapter is organized in the following way. In Section 2, we will discuss the properties of remnant movement and examine the conditions that govern its availability. In Section 3, we will provide a novel account of restructuring in terms of remnant movement and discuss the implications of this account for the theory of remnant movement. In Section 4, we will outline a restrictive theory of deletion and show that it can derive the cases of Discontinuous constituents discussed by Ćavar and Fanselow 1998. In Section 5, we will come back to our cases of conflicting structural requirements and explain in detail why they should be handled in terms of remnant movement rather than in terms of partial deletion.

\section{Remnant Movement}

Remnant movement seems to be exempted from the Proper Binding Condition $(\mathrm{PBC})$, which requires that traces be bound. It is typical of remnant movement to create unbound traces as is illustrated below. In (7), the fronted VP contains the trace of the direct object which is not c-commanded by its antecedent.

(7) VvP $_{\mathrm{SCR}}$ gelesen] hat Hans [das Buch $]_{\mathrm{SCR}} t_{\mathrm{VP}}$

Remnant movement typically also leads to so-called Anti-Freezing effects. A Freezing effect occurs if extraction of constituent $a$ out of a constituent $b$ takes place in a derived position of $b$. This is illustrated in (8ab). In (8a), extraction took place from the base position of the direct object. In (8b), the direct object has been scrambled to a higher position from which extraction is excluded. 
(8) a. Worüber $\mathrm{i}_{\mathrm{i}}$ hat keiner [ein Buch $\mathrm{t}_{\mathrm{i}}$ ] gelesen. where-about has nobody a book read

b. ${ }^{\star}$ Worüber $_{\mathrm{i}}$ hat [ein Buch ti] keiner gelesen. where-about has a book nobody read 'Which topic has nobody read a book about.'

c. [Ein Buch $t_{i}$ ] hat darüber $r_{i}$ keiner gelesen. a book has there-about nobody read 'Nobody has read a book about that.'

Example (8c) is a case of remnant movement. From a representational point of view, (8c) should be as bad as (8b), since the direct object in (8c) occurs in a derived position and contains a trace created by extraction. However, if we look at these cases from a derivational point of view, we immediately understand why $(8 b)$ is ungrammatical and $(8 c)$ is fine. The difference follows from the Extension Condition on derivations (Strict Cyclicity). In (8c), it is possible to extract the PP out of the DP in its base position and then move the remnant DP, obeying the Extension Condition, to a higher position. This derivation, however, is not available in ( $8 b)$. If the PP were extracted first, movement of the remnant DP to a lower position would violate cyclicity. Thus, we see that obeying the Extension Condition voids in a manner of speaking- freezing effects but necessarily leads to unbound traces. Consequently, we may assume that the $\mathrm{PBC}$ is not a derivational constraint.

Furthermore, as Müller in his seminal work on incomplete category fronting has discussed at length (cf. Müller 1996), cases of remnant movement display unexpected asymmetries. As is illustrated in (9), remnant categories can be topicalized, while scrambling may not affect them. This asymmetry does not show up in cases of complete category fronting (10).

(9) a. [zu lesen] hat das Buch keiner versucht. to read has the book nobody tried-PART 'Nobody has tried to read the book.'

b. ??daß [zu lesen] das Buch keiner versucht hat. that to read the book nobody tried has 'That nobody has tried to read the book.'

(10) a. [das Buch zu lesen] hat keiner versucht. the book to read has nobody tried-PART 'Nobody has tried to read the book.' b. Daß [das Buch zu lesen] keiner versucht hat. that the book to read nobody tried has that nobody has tried to read the book.'

Müller concludes from these observations that remnant XPs cannot undergo Y-movement if the antecedent of the unbound trace has also undergone Ymovement, where Y-movement ranges over scrambling, wh-movement and topicalization. Müller (1996) derives this constraint on remnant movement from his Principle of Unambiguous Domination which is motivated by the need of traces, so Müller assumes, to be unambiguously identifiable.

There are several problems with Müller's account though. First, there are cases where remnant categories can undergo scrambling, as we will see in 3.2. Secondly, various cases where remnant categories cannot scramble can be reduced to independent restrictions on the individual operations involved, as we will argue in Section 3.2. Thirdly, Müller's principle of Unambiguous Domination lacks conceptual plausibility in a theory of movement in terms of copy and delete, i.e., in a theory where there are no traces to be identified and, as we will see, fails to explain the parallelism to partial deletion.

From the point of view of feature checking, Müller's observations indicate that for remnant movement to be possible two sets of features must be involved that cannot be checked in the same (type of) position. Thus, Müller's generalisation can be derived from Attract Closest (Chomsky 1995), as is illustrated in (11). In order for a (remnant) category A to undergo scrambling, extraction of $B$ out of A must involve a type of movement other than scrambling.

(11) $\mathrm{F}_{\mathrm{SCR}} \ldots\left[_{\mathrm{A}}^{\mathrm{SCR}} \ldots\left[_{\mathrm{B}}^{\mathrm{SCR}} \ldots\right]\right]$

There is a class of cases of remnant movement which are illicit although they obey Attract Closest (or Unambiguous Domination, for that matter). These involve topicalization of a remnant category out of which a category has been extracted via wh-movement as is illustrated in (12). (12a) is a case of topicalization of a clause across a wh-island which leads to a mild, subjacency-like violation. (12b), where the wh-word is extracted from the embedded clause (creating a remnant category), however, is ungrammatical. The same contrast can be observed in English, as is shown in (13) taken from Pesetsky (1998). The relative grammaticality of $(12 \mathrm{c})$ is interesting in this respect. If the trace of the wh-word were contained in the fronted VP, as is standardly assumed, then (12c) should be on a par with (12b) and (13b). However, it is just as good as (12a). We will come back to this difference and show how it is to be explained in Section 3.1. 
(12) a. ??[daß Fritz Peter liebt] weiss ich nicht wer gesagt hat. that Fritz loves Peter know I not who has said 'I don't know who has said that Fritz loves Peter.'

b. ${ }^{*}[\mathrm{daB}$ Fritz $t \quad$ liebt $]$ weiss ich nicht wen er gesagt hat. [that Fritz loves $\mathrm{t}$ ] know I not who he has said 'I don't know who he said that Fritz loves.'

c. ?? [geküßt] weiss ich nicht wen sie hat.

[kissed] know I not whom she has

I don't know whom she has kissed.'

(13) a. [give a book to John] I can guess who will.

b. ${ }^{\star}$ [give a book to $t$ ] I can guess who Mary will.

(I can guess who Mary will give a book to)

It is not clear why wh-movement differs in this respect from other types of movement. In other words it is not clear why the PBC nevertheless seems to be relevant for wh-movement. Given that the PBC is not a derivational constraint we may assume that the cases in $(12 \mathrm{a}, \mathrm{b})$ and (13) create illegitimate LF-objects, since the operator does not bind its variable. Pesetzky (1998) assumes that there is a (special) command restriction on wh-movement. We will leave this question open here and conclude from the above discussion that as long as we steer clear of extraction via wh-movement, remnant movement is freely available if Attract Closest and Strict Cyclicity are obeyed.

\section{Restructuring and Remnant Movement}

It is important to note that the topicalization of verbal projections is dependent on restructuring. In (14a), where the matrix verb vergessen is a restructuring verb, topicalization of the embedded infinitive is licit. In (14b), where the matrix verb verzichten is not a restructuring verb, the topicalization of the embedded infinitive is ungrammatical. In the standard account, the contrast in (14) is explained by assuming that restructuring verbs permit embedded arguments to move into the matrix domain, creating a remnant category that can be fronted. However, we will argue that what has fronted in (14) is not a remnant infinitive but just the infinitival VP.

(14) a. [zu lesen] hat Hans das Buch vergessen. to read has Hans the book forgotten Hans has forgotten to read the book.' b. ${ }^{*}$ zu lesen] hat Hans das Buch verzichtet.

to read has Hans the book refrained from

Hans refrained from reading the book.'

\section{An account of restructuring in terms of Remnant Movement}

In Hinterhölzl (1999), we argue in favor of a VO-based, biclausal account of restructuring and show that the standard analysis in terms of Verb Raising (VR) and Long distance scrambling (LDS), as illustrated in (15), is untenable. VR is an operation of head-movement that adjoins (right-adjoins, in the case of (15)) the dependent infinitive to the selecting verb. LDS is an operation that moves arguments of the infinitival verb into the matrix domain to account for the so-called Clause-Union phenomenon. In the case of (15), the embedded object is scrambled out of the embedded clause, across matrix negation into the middle field of the matrix clause.

(15) Dat wij de kraaien $n_{L D S}$ niet $\left[t_{L D S} t_{V R}\right.$ ] zagen vliegen $n_{V R}$ that we the crows not saw fly that we didn't see the crows fly.

In Hinterhölzl (1999), we demonstrate with the help of particle verbs in Dutch that verb cluster formation involves movement of the (extended) infinitival VP. Here, we will outline only one piece of evidence that shows that VR is XPmovement and that comes from the position of the infinitival marker. In the standard account, the sequence op te bellen in (16a) has to be analyzed as a complex head. However, in Hinterhölzl (1999) we show that the infinitival marker can neither be analyzed as a verbal prefix (in the VP) or as occupying a head final functional position within the IP-domain to which the infinitival verb has been right-adjoined via head movement. Instead, Hinterhölzl (1999) argues that the infinitival marker occupies a functional head to the left of VP, which Haegeman (1995) called F1 and adopts a VO-based approach. In this approach, the sequence op te bellen is to be analyzed as given in (16b) with the particle undergoing licensing XP-movement to [SpecF1P].

(16) a. Dat Jan Marie $t_{R}$ probeerde [op te bellen $]_{R}$. that Jan Marie tried up to call that Jan tried to call up Marie.'

b. $\quad{ }_{\mathrm{FIP}}\left[{ }_{\mathrm{XP}} \text { op }\right]_{\mathrm{i}}\left[\right.$ te [VP bellen $\left.\mathrm{t}_{\mathrm{i}}\right]$ 
The main problem that a VO-based account of restructuring faces is the question of how to account for the distribution and interpretation of elements belonging to the dependent infinitive (its arguments and adverbs modifying it). If we look at a typical case of VR in Dutch (cf. (17ab)), then we realize that the nominal arguments of the infinitive and adverbs and adverbials modifying it precede the selecting verb wilde while the infinitive itself (and a sentential complement of the infinitive) follow the selecting verb. In (17), constituents given in square brackets belong to the embedded clause. In a VO-based account, we have to assume that a restructuring infinitive like (17a) is derived from an underlying structure of the type given in (17b).

(17) a. Dat Jan [Marie het boek morgen] wilde [geven]. that Jan Marie-DAT the book tomorrow wanted give

'That Jan wanted to give Marie the book tomorrow.'

b. Dat Jan wilde [ PRO Marie het boek morgen geven ].

The simplest possibility of relating the structure in (17a) with the underlying structure in (17b) is to assume that the bracketed constituents preceding the matrix verb have been moved individually via scrambling from the embedded clause into the matrix clause. However, Hinterhölzl (1999) argues that scrambling (alone) cannot be the solution to this problem. Here we can only outline the main arguments. The first argument is that verb particles, small clause predicates and idiomatic expressions resist scrambling (cf. (18b)) but can appear in the matrix clause in restructuring contexts as is illustrated in (18c) for adjectival small clause predicates.

(18) a. Dat Jan de schuur gisteren rood schilderde. that Jan the barn yesterday red painted

b. ??dat Jan de schuur rood gisteren schilderde. that Jan the barn red yesterday painted that Jan painted the barn red yesterday.'

c. Dat Jan de schuur rood wil schilderen. that Jan the barn red wants paint that Jan wants to paint the barn red.'

The second argument concerns the distribution of adverbs. It is generally assumed that adverbs cannot scramble (cf. Cinque 1997). But even if it is assumed that adverbs in restructuring contexts can scramble or undergo some type of licensing movement into the matrix clause one would assume that they move/scramble to their canonical position in the clause. However, the order of adverbs in (19a) does not reflect the base order. The temporal adverb modifying the embedded verb follows the aspectual adverb modifying the matrix verb. In a simple clause, only the inverted order is possible (19b-d).

(19) a.
Weil Peter mich schon lange
heute besuchen wollte. since Peter me already for-a-long-time today visit wanted Already for a long time has Peter wanted to visit me today.'
b. ${ }^{*}$ Weil mich Peter schon lange heute besucht hat. since me Peter already for-a-long-time today visited has

c. *Weil das Peter schon lange heute wollte. since that Peter already for-a-long-time today wanted

d. Weil mich Peter heute schon lange besucht hat. since me Peter today already for-a-long-time visited has 'Since Peter has already visited me for a long time today.'

Instead of scrambling, Hinterhölzl (1999) assumes movement of a larger constituent, namely the whole infinitival TP, that pied-pipes arguments of the embedded verb and adverbs modifying it and (VP-internal) predicates. The order of adverbs in (19a) is explained in that it is assumed that the middle field of a restructured clause contains two TPs and can be derived as is sketched in (24) below.

In order for this account to go through, Hinterhölzl (1999) argues that not only arguments but also VP-internal predicates moye out of the VP to be licensed in specific positions in the middle field as is/illustrated in (20).

(20) $\left[\mathrm{DPs}\left[\mathrm{Neg}^{0}\left[\operatorname{Focus}^{0}\left[\mathrm{DPs}\left[\mathrm{VP}-\mathrm{adverbs}\left[\operatorname{Pred}^{0}[\mathrm{~F} 1[\mathrm{VP} \mathrm{V}]]\right]\right]\right]\right]\right]\right.$

Verb particles are licensed in [SpecF1P]. Small clause predicates, idiomatic expressions and directional PPs are licensed in [SpecPredP] above F1. Nominal arguments of the verb undergo Case-licensing movement to positions above VP-adverbs. From there they may undergo scrambling to higher positions (according to their semantic properties) if they are not focussed or negated, in which case they move into the respective Specifier position. Thus, movement of arguments out of the VP is licensing movement that applies to all DPs independently of whether they are definite or indefinite and has to be distinguished from further movement that applies to DPs according to their semantic properties and has become known as scrambling.

The assumption of licensing movement of VP-internal material that is to be distinguished from scrambling 'proper' is supported by the fact that it can solve 
two long-standing problems with the standard account of VP-topicalization data like (1) in terms of scrambling and remnant movement: the extraction paradox (A) and the evacuation paradox (B), which are discussed and illustrated below.

(A) The assumption that there is licensing movement of VP-internal material to specific positions in the middle field is corrobated by the existence of so-called string vacuous scrambling as is illustrated in (21). In (21), the italicized phrases seemingly occur in their canonical position (in (21b) the direct object follows the subject) but have to be assumed to have been scrambled out of VP in order to be exempted from VP-topicalization.

(21) a. [ ${ }_{\mathrm{VP}} \mathbf{t}$ gerechnet] hat wie immer keiner damit. counted has as always noone there-with as usual nobody has reckoned with that.'

b. [ ${ }_{\mathrm{vP}} \mathrm{t}$ gelesen] hat gestern der Fritz ein Buch darüber. read-PART has yesterday the Friz a book there-about Fritz has read a book about this yesterday.'

As (22) shows these presumed scrambling positions do not behave like regular scrambling positions since they do not exhibit any freezing effect (cf. (8)) in that they allow for further extraction which scrambles part of the phrase to a higher position. Thus, the data in (22) pose the following problem: If scrambling viewed as an operation that moves VP-internal material into the middle field were a unitary operation, then why is that scrambled phrases allow for futher extraction in certain positions but not in others?

(22) a. Gerechnet hat da wie immer keiner mit. counted has there as always noone with

b. Gelesen hat darüber gestern der Fritz ein Buch. read has there-on yesterday the Fritz a book

(B) Another problem for the standard approach is the fact that elements that resist scrambling can be left behind by VP-topicalization. This is illustrated for small clause predicates and indefinite $\mathrm{W}$-words in (23a) and (23b), respectively. We have seen in (18) above that small clause predicates cannot be affected by scrambling. Furthermore, indefinite w-words exhibit none of the quantificational or referential potential that is held responsible for triggering scrambling. If scrambling were the only operation that can evacuate material from the VP, then it is hard to understand, how these elements can be left behind by VP-topicalization.
(23) a. Gegessen hat der Karl das Fleisch roh. eaten has the Karl the meat raw Karl has eaten the meat raw

b. Gelesen hat die Maria erst gestern was. read-PART has the Maria only yesterday something 'Its only yesterday that Mary read something.'

c. ?? $t_{i}$ geküßt $]_{j}$ weiß ich nicht $\left[\right.$ wen $_{i}$ sie hat $\left.t_{j}\right]$. kissed know I not whom she has 'I don't know whom she has kissed.'

A possible solution to these problems is the assumption of licensing movement (prior to scrambling) that moves VP-internal material, irrespective of its quantificational or referential potential out of the VP. This assumption immediately solves the evacuation problem but also opens up the way towards a solution to the extraction problem. Given the distinction between licensing movement and scrambling, we may assume that licensing movement out of the VP does not give rise to a freezing effect and that this freezing effect is connected with the Specificity effect of the semantically motivated scrambling operation. We know independently that extraction out of specific DPs is illicit. Since DPs that have scrambled across sentential adverbs (crucially not ones that have scrambled across VP-adverbs) exhibit a specificity effect, the freezing effect associated with these scrambling operations follows without further ado.

Finally note that the trace within the VP in (23c) does not behave like a Case-marked wh-trace, otherwise we would expect (23c) to be on a par with (12b) and (13b). However, (23c) gives rise only to a mild, subjacency-like violation and is on a par with (12a), as we have seen in Section 2 above. This fact too follows straightforwardly, if we assume that there is licensing movement of DPs (and of VP-internal predicates) out of the VP that leaves Amovement traces in the VP such that the wh-word in the embedded clause can bind a wh-trace outside of the fronted VP within its clause. To summarize, we have argued that the assumption of movement of DPs and VP-internal predicates to specific licensing positions in the middle field, as illustrated in (20) above, can provide a solution to the extraction problem as well as the evacuation problem and gives us an explanation for the otherwise rather mysterious contrast between (12b) and (12c).

Based on the assumption that the VP is emptied up to the verb, Hinterhölzl (1999) develops a theory of restructuring that makes heavy use of remnant movement and proposes that restructuring breaks down into three 
movement operations that occur for licensing purposes, as is illustrated in (24):

(A) Movement of the infinitival VP via [Spec CP] (Step 1) into [SpecF1P] of the selecting verb (Step 2)

(B) movement of the infinitival TP into [SpecPredP] of the selecting verb (Step 3)

(C) movement of the infinitival T-head to the local T-head (Step 4)

Step 1 occurs to license the deficient complementizer as a $[+\mathrm{V}]$ element Step 2 occurs to check the subcategorization of the selecting verb (its status) Step 3 occurs to license the embedded TP as a predicate

Step 4 occurs to license PRO creating a single extended projection as a sideeffect

(24) a. $\left[_{\mathrm{CP}}\right.$ weil $\left[_{\mathrm{TP}}\right.$ Peter schon lange $\left[_{\mathrm{PredP}}\left[_{\mathrm{FIP}}\left[_{\mathrm{VP}}\right.\right.\right.$ wollte $\left[_{\mathrm{CP}}\left[_{\mathrm{TP}}\right.\right.$ mich heute $\left[{ }_{F 1 P}\right.$ besuchen] $\left.\left.\left.\left.]\right]\right]\right]\right]$

Step 1: movement of the infinitival VP to SpecCP

b. $\left[_{\mathrm{CP}}\right.$ weil $\left[_{\mathrm{TP}}\right.$ Peter schon lange $\left[_{\mathrm{PredP}}\left[_{\mathrm{FIP}}\left[_{\mathrm{VP}}\right.\right.\right.$ wollte

[CP $\left[{ }_{F 1 P}\right.$ besuchen] $\left[_{T P}\right.$ mich heute $\left.\left.\left.\left.\left.t_{F 1 P}\right]\right]\right]\right]\right]$

Step 2: movement of the infinitival VP to SpecF1P (if only Step 1 and Step 3 occur overtly the normal Dutch order is derived)

c. [CP weil $\left[_{T P}\right.$ P. schon lange $\left[_{\text {PredP }}\left[_{F I P}\left[\right.\right.\right.$ FIP besuchen] $\left[_{V P}\right.$ wollte $\left[\mathrm{CP} \mathbf{t}_{\mathrm{FIP}} \cdot\left[\mathrm{TP}\right.\right.$ mich heute $\left.\left.\left.\left.\left.\mathrm{t}_{\mathrm{FIP}}\right]\right]\right]\right]\right]$

Step 3: movement of the infinitival TP into SpecPredP

d. [ ${ }_{\mathrm{CP}}$ weil $\left[_{\mathrm{TP}} \mathrm{P}\right.$. lange $\left[_{\mathrm{PredP}}\left[_{\mathrm{TP}}\right.\right.$ mich heute $\left.\mathrm{t}_{\mathrm{FIP}}\right]\left[_{\mathrm{FIP}}\left[{ }_{\mathrm{FIP}}\right.\right.$ besuchen $]$ $\left[\mathrm{VP}\right.$ wollte $\left.\left.\left[\mathrm{CP}_{\mathrm{F} 1 \mathrm{P}} \mathrm{t}_{\mathrm{TP}}\right]\right]\right]$

Step 4: T-to-T-movement allows for local scrambling and cliticization

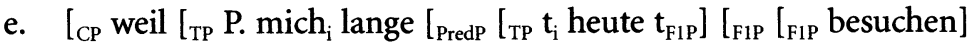
[VP wollte $\left.\left.\left[{ }_{\mathrm{CP}} \mathbf{t}_{\mathrm{F} 1 \mathrm{P}} \mathbf{t}_{\mathrm{TP}}\right]\right]\right]$

\subsection{Implications of this Account for the Theory of Remnant Movement}

In this account of restructuring, embedded infinitives can no longer be analyzed as (possibly referential) remnant categories that contain scrambling traces. Thus, the illicit cases of remnant scrambling can no longer be ruled out by Attract Closest. In this account, embedded infinitives are simply infinitival VPs that contain traces of licensing movement, among which, traces left behind by Case movement. In particular, we have to find another explanation for the fact that these infinitival VPs may topicalize but cannot undergo scrambling in the matrix clause as is illustrated again in (25).

(25) a. [zu lesen] hat das Buch keiner versucht.

to read has the book nobody tried-PART Nobody has tried to read the book.'

b. ??daß [zu lesen] das Buch keiner versucht hat

that to read the book nobody tried has that nobody has tried to read the book.'

Our explanation of the contrast is rather simple. These infinitival VPs are predicates and as such resist scrambling. This explanation is based on the assumption that [SpecCP], the so-called topicalisation position, is a multipurpose position that can host focussed phrases, which are not necessarily referential as well as discourse topics and sentence topics. While discourse topics are necesssarily referential (token topics), sentence topics can be predicates or so-called type topics.

If we assume that only quantificational expressions (for reasons of scopetaking) and token-topics may scramble, then we can rule out scrambling of predicates including VPs - given the natural assumption that the VP denotes an event type (with the TP denoting an event-token). That the correct generalisation is indeed unavailability of predicates for scrambling, is shown in (26). (26) shows that scrambling of a predicate is equally bad whether it is the entire predicate as in (26a) or only a remnant as in (26b) that undergoes scrambling.

(26) a. ??daß [die Maria geliebt] Hans hat. that the Maria loved Hans has

b. ??daß [geliebt] Hans die Maria hat that loved-PART Hans the Maria has 'That Hans has loved Maria'

This observation is corrobated by the following facts. There is a type of scrambling that Neeleman (1994) termed focus-scrambling, but really involves a contrastive topic, which may also apply to predicates, as is shown by the contrast between (27a) and (27b). (27a) involves illicit scrambling of the adjectival predicate across the position of the direct object. (27b) involves 
scrambling of a contrastive topic to the top of the middle field and is fine. As (27c) shows this type of scrambling is also possible of a remnant VP.

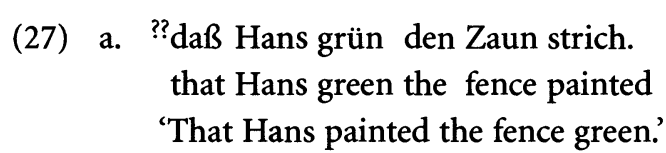

b. Daß so grün nur der Hans den Zaun streichen würde. that so green only the Hans the fence paint would 'That only Hans could paint the fence so green.'

c. Daß so geliebt die Maria nur er hat. that so loved the Maria only he has 'That only he loved Maria to such a degree.'

\section{Partial Deletion}

In Hinterhölzl (2000), we argue that cases of PP-out-of-NP, as illustrated in (28), should not be accounted for in terms of extraction of the PP, be it rightward extraction (extraposition) or leftward extraction plus subsequent remnant movement. There, we showed that the stress properties and the focus potential of these postverbal PPs indicate that no extraction out of NP took place. As is illustrated in (29), these PPs can receive nuclear stress and give rise to a wide focus reading. Furthermore, we showed that the well-known differences between leftward and rightward extractions - no leftward extraction out of subjects as illustrated in (30) and no leftward extraction out of specified NPs, as is illustrated in (31) - cannot be explained in terms of different extraction paths as proposed by Müller (1995).

(28) Hans hat ein Buch (über Chomsky) gekauft (über Chomsky) Hans has a book (about Chomsky) bought (about Chomsky) 'Hans has bought a book about Chomsky.'

(29) What happened?

Ich glaube daß Hans ein Buch gekauft hat über Chomsky.

I believe that Hans a book bought has about Chomsky

'I believe that Hans has bought a book about Chomsky.'

(30) a. *Über Chomsky hat mir [kein Buch t] gefallen. about Chomsky has me-DAT no book liked 'I did not like any book about Chomsky.' b. Weil mir [das Buch $\mathrm{t}$ ] gefallen hat über Chomsky. since me-DAT the book liked has about Chomsky since I liked the book about Chomsky.'

(31) a. * Who did you see the picture of.

b. Hans hat das Buch gelesen über Chomsky. -Hans has the book read about Chomsky Hans has read the book about Chomsky.

Instead, we argued that these cases can be handled appropriately in terms of partial deletion. Partial deletion is based on the copy-theory of movement and employs the idea that no mechanism in the computational system forces that the entire copy is spelled out in the checking position, as illustrated in (32a), but may make use of selected processes of Forward Deletion (FWD) and Backward Deletion (BWD), as is illustrated in (32b). ${ }^{1}$ Hinterhölzl (2000) outlines a restrictive theory of deletion in which Spell-out is tied to the particular execution of the feature checking mechanism proposed by Nunez (1995). In this system of feature checking, only the feature of the copy that merges with the target category is checked. The corresponding feature of the copy in the base position remains unchecked and, if uninterpretable, causes the derivation to crash unless removed by complete phonological deletion. It thus follows that the computational system does not impose any restriction on the Spell-out of pied-piped material (cf. (33)).

(32) a. $\left[{ }_{\mathrm{C}} \mathrm{X} Y\right] \ldots \ldots\left[_{\mathrm{C}} \mathrm{X} Y\right]$ standard case: one copy completely deleted. b. $\left.\left[{ }_{C} X ¥\right] \ldots . .{ }_{C} X Y\right]$ FWD of $X$ plus BWD of $Y$.

(33) Free Deletion of Pied-piped Material (FDPM) (cf. Hinterhölzl (2000))

a. Material that is moved to check a feature is subject to FWD.

b. Material that is pied-piped by such movement is subject to optional. BWD

\subsection{Deriving Discontinuous NPs}

Ćavar and Fanselow (1998) argue convincingly that Discontinuous NPs (DNPs), as given in (34), should be handled in terms of partial deletion. C\&F show that DNPs cannot be explained by base generation since DNPs obey island constraints - indicating that DNPs involve movement- and respect order constraints observable in single complete NPs. C\&F also show that 
DNPs cannot be explained in terms of partial movement either since they do not obey conditions on extractions out of DPs as is illustrated in (35).

(34) Englische Bücher hat er keine gekauft English books has he none bought He did notuy any English books.

(35) a. * Öber Chomsky hat ihm kein Buch gefallen. about Chomsky has him no book pleased No book about Chomsky did please him.

b. [Bücher über Chomsky] haben ihm keine gefallen. books about Chomsky have him none pleased No books about Chomsky did ever please him.'

In the following, we will show how cases like (34) can be derived within the theory of deletion outlined above. Since (33) restricts BWD to pied-piped material it follows that (34) must involve two movement operations that check two different types of features: An operation of topicalization that moves the entire DP into [SpecCP] and a prior focus-related movement that pied-pipes the topicalized constituent (cf. Ćavar and Fanselow 1998). (36b) shows the underlying feature structure. We assume that the topic feature is checked in [SpecCP] and that the (constrastive) focus feature is checked in a Focus Phrase that occurs just above the licensing positions of the arguments of the verb (cf. (20) above).

(36) a. Englische Bücher hat er keine gekauft.

b. $\quad{ }_{\mathrm{CP}}^{\mathrm{T}}$ hat $\left[{ }_{\mathrm{IP}}\right.$ er $\left[{ }_{\mathrm{FP}}^{\mathrm{F}}{ }_{\mathrm{AgrOP}}\left[{ }_{\mathrm{DP}}\right.\right.$ keine $_{\mathrm{F}}$ englische ${ }_{\mathrm{T}}$ Bücher $\left._{\mathrm{T}}\right]$ gekauft $\left.\left.\left.]\right]\right]\right]$

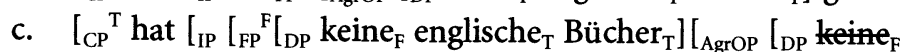
englische ${ }_{T}$ Bücher $_{\mathrm{T}}$ ] gekauft]]]]

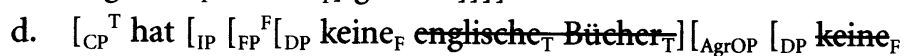
englische $_{\mathrm{T}}$ Bücher $_{\mathrm{T}}$ ] gekauft]]]]

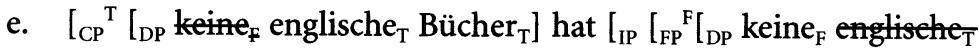
Büretrer $\left.\left.\left.]\left[{ }_{\text {AgroP }} t_{D P}\right]\right]\right]\right]$

First the DP is moved into [SpecFP] to check the focus feature of the head. This operation pied-pipes the remaining elements in the DP that carry a topic feature. The head keine of the DP is subject to FWD. This is illustrated in (36c). The remaining elements of the DP are subject to optional BWD. However, in (36c) BWD is forced by Attract Closest. The T-feature in C attracts the closest phrase containing constituents marked with a T-feature.
This phrase is the DP in [SpecFP]. Since the constituents marked with a Tfeature cannot extract out of DP and since focus is a positional feature, as we will explain below, FWD of englische Bücher would not result in a convergent derivation. The conflict can be resolved if these elements are effected by BWD as in (36d). In this case, the T-feature will attract the copy in the base position resulting in the correct derivation as shown in (36d).

In checking an interpretable feature either copy may be spelled out unless the attracting head has a positional feature. A positional feature requires that the attractee is spelled out in the checking domain of the attractor (cf. Pesetsky 1998). Typical examples of positional features in many languages are [wh], [neg] and [focus]. Which head in a given language has a positional feature is subject to crosslinguistic variation.

Note that even if we assume that extraction of NPs out of DPs is different from extraction of PPs (cf. (35)), which seems unmotivated, an account of (36a) in terms of remnant movement is impossible. If the elements Englische Bücher were extracted out of the base position of the object DP, subsequent movement of the DP to [SpecFP] would lead to a violation of Strict Cyclicity. If these elements were extracted from within [SpecFP] we would expect a Freezing effect. ${ }^{2}$

Since cases of partial deletion cannot be reduced to remnant movement and since both operations yield similar results the question arises whether in turn remnant movement can be reduced to partial deletion. Before we look at specific cases in the next section, we want to investigate whether there are any further restrictions on deletion.

In looking at additional examples, we will make the following assumption about pied-piping: the head plus constituents agreeing with it (the Specifier) may induce movement of the whole phrase (typically, pied-piped constituents are complements of the head).

Assuming that Bücher as the head, furnishing new information, can induce pied-piping of the whole phrase into [SpecFP], the ungrammaticality of (37) shows that BWD may not affect left peripheral material. The illicit step occurs in (37d), if BWD could affect the expression $n e u e_{\mathrm{T}}$ then the derivation of (37a) would converge, contrary to the fact. (38) shows that BWD may not affect medial material. Again, the illicit step seems to occur in (38d) where the expression englische ${ }_{T}$ is affected by BWD. From (37) and (38) we may thus conclude that BWD can only affect right peripheral material in a phrase. 
(37) Was für neue Sachen hat Hans gekauft?

Which new things did Hans buy?

a. ${ }^{\star}$ Neue hat Hans Bücher gekauft. new has Hans books bought

b. $\left[{ }_{C P}^{\mathrm{T}}\right.$ hat $\left[{ }_{\mathrm{IP}}\right.$ Hans $\left[{ }_{\mathrm{FP}}^{\mathrm{F}}\left[{ }_{\mathrm{AgrOP}}\left[{ }_{\mathrm{DP}}\right.\right.\right.$ neue $_{\mathrm{T}}$ Bücher $\left._{\mathrm{F}}\right]$ gekauft $\left.\left.\left.]\right]\right]\right]$.

c. ${ }_{C \mathrm{CP}}^{\mathrm{T}}$ hat $\left[_{\mathrm{IP}}\left[{ }_{\mathrm{FP}}^{\mathrm{F}}\left[{ }_{\mathrm{DP}}\right.\right.\right.$ neue $_{\mathrm{T}}$ Bücher $\left._{\mathrm{F}}\right]\left[_{\mathrm{AgrOP}}{ }_{\mathrm{DP}}\right.$ neue $_{\mathrm{T}}$ ü̈e $\left._{\mathrm{F}}\right]$ gekauft]]]].

d. $\left[{ }_{C P}^{\mathrm{T}}\right.$ hat $\left[_{\mathrm{IP}}\left[{ }_{\mathrm{FP}}^{\mathrm{F}}\left[{ }_{\mathrm{DP}}\right.\right.\right.$ Bücher $\left._{\mathrm{F}}\right]\left[_{\mathrm{AgrOP}_{\mathrm{F}}}\left[_{\mathrm{DP}}\right.\right.$ neue $_{\mathrm{T}}$ Bücher $\left._{\mathrm{F}}\right]$ gekauft]]]] illicit BWD

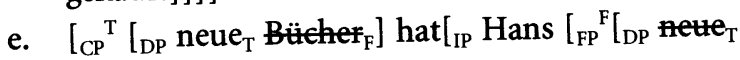
Bücher $\left._{\mathrm{F}}\right]\left[\right.$ AgrOP $\left.\left.\left.\left._{\text {gekauft }}\right]\right]\right]\right]$

(38) Was für Englische Sachen hat Hans gekauft?

Which English things did Hans buy?

a. *Englische hat Hans viele Bücher gekauft. English has Hans many books bought

b. $\left[{ }_{\mathrm{CP}}^{\mathrm{T}}\right.$ hat $\left[{ }_{\mathrm{IP}}\right.$ er $\left[{ }_{\mathrm{FP}}^{\mathrm{F}}{ }^{\mathrm{AggrOP}}\left[{ }_{\mathrm{DP}}\right.\right.$ viele $_{\mathrm{F}}$ englische $\mathrm{T}_{\mathrm{T}}$ Bücher $\left._{\mathrm{F}}\right]$ gekauft $\left.\left.]\right]\right]$.

c. ${ }_{C \mathrm{CP}}^{\mathrm{T}}$ hat $\left[_{\mathrm{IP}}\left[{ }_{\mathrm{FP}}^{\mathrm{F}}\left[_{\mathrm{DP}}\right.\right.\right.$ viele $_{\mathrm{F}}$ englische ${ }_{\mathrm{T}}$ Bücher $\left._{\mathrm{F}}\right]\left[_{\mathrm{AgrOP}}\left[{ }_{\mathrm{DP}}\right.\right.$ iele $_{\mathrm{F}}$ englische $_{\mathrm{T}}$ üher $_{\mathrm{F}}$ ] gekauft]]]]

d. $\left[{ }_{C P}^{\mathrm{T}}\right.$ hat ${ }_{I P}\left[{ }_{\mathrm{FP}}^{\mathrm{F}}\left[{ }_{\mathrm{DP}}\right.\right.$ viele $_{\mathrm{F}}$ Bücher $\left._{\mathrm{F}}\right]\left[_{\mathrm{AgrOP}}\left[_{\mathrm{DP}}\right.\right.$ iete $_{\mathrm{F}}$ englische $_{\mathrm{T}}$ Bücher $_{\mathrm{F}}$ ] gekauft]]]]

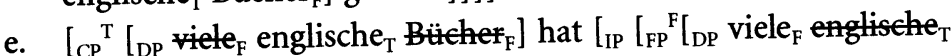
Bücher $\left._{\mathrm{F}}\right]\left[{ }_{\text {AgrOP }}\right.$ gekauft $\left.\left.\left.]\right]\right]\right]$

\section{Cases of conflicting structural requirements}

To see whether partial deletion can indeed replace remnant movement, let us take a closer look at our cases of conflicting structural requirements which are repeated in (39). Given what we discovered about the restrictions on deletion in the previous section, we can immediately rule out the analysis in (39a) since it involves medial deletion. Thus cases like (39a) must be handled in terms of remnant movement.

(39) a. [fragen ob wir zustimmen] wird er wohl [ müssen ob.....].

b. [ein Haus bauen whenten] wird er [ein wollen].

c. [ er wird [ ${ }_{\text {PredP }}$ ein Haus [FIP bauen wollen]]].

The analysis in (39b) is valid since it involves a simple case of BWD of right- peripheral material. Since after restructuring the embedded object and the embedded infinitive do not form a constituent anymore, as is illustrated in (39c), topicalization of these elements would involve movement of the entire PredP pied-piping the modal which is thus subject to BWD. However, there is an interesting asymmetry that indicates that also cases like (39b) should be handled in terms of remnant movement.

There is a clear asymmetry between bare infinitives and to-infinitives with respect to the topicalizability of verbal projections as is shown by the contrast in (40).

(40) a. Ein Buch geben hat er seiner Frau wollen. a book give has he his wife wanted 'He wanted to give a book to his wife.'

b. ??ein Buch zu geben hat er seiner Frau vergessen a book to give has he his wife forgotten 'He forgot to give a book to his wife.'

Haider (1991) notes that with to-infinitives either the whole infinitival clause (41b) or the verb cluster (or parts of it) can be topicalized (41e), but not the infinitive with one of its arguments $(41 \mathrm{c}-\mathrm{d})$. It is hard to see how this asymmetry can be accounted for by an analysis in terms of partial deletion.

(41) a. Daß er mir sein Argument zu erläutern zu versuchen vergessen hat. that he me his argument to explain to try forgotten has

b. [mir sein Argument zu erläutern] hat er zu versuchen vergessen. me his argument to explain has he to try forgotten

c. ${ }^{*}$ [sein Argument zu erläutern] hat er mir zu versuchen vergessen. his argument to explain has he me to try forgotten

d. ${ }^{*}$ [sein Argument zu erläutern zu versuchen]] hat er mir vergessen. his argument to explain to try has he forgotten

e. [zu erläutern zu versuchen vergessen] hat er mir sein Argument to explain to try forgotten has he me his argument nicht

not

'(That) he has (not) forgotten to try to explain me his argument.'

We will not give a full account of the above contrast here but will, on the way towards an explanation of the contrast, make note of the facts that point to an account in terms of movement. It is important to note that the verbs that show the dual behavior (topicalization of the dependent infinitive with an 
argument (42b) or with the selecting verb (42a)) are exactly those verbs that can invert with the rest of the verb cluster. The basic order in the German verb cluster is V3-V2-V1. But temporal auxiliaries and modals can optionally enter into inverted orders of the type V1-V3-V2 (cf. Geilfuß (1990), Haftka (1991)). Also note that nominal arguments can appear in the verbal cluster in inverted orders as is illustrated in (42d).

(42) a. Backen können wird er einen Kuchen müssen bake can will he a cake must 'He will have to be able to bake a cake.'

b. Einen Kuchen backen wird er können müssen.

c. Daß er einen Kuchen wird müssen backen können (V1-V2-V4-V3).

d. Daß er nach langer Ausbildung wird einen Kuchen backen können. that he after long training will a cake bake can that he must be able to bake a cake (after long training).'

The inversion facts suggest that auxiliaries and modals can move higher up in the clausal domain. If we assume that they can move across PredP, then the VP-topicalization facts follow as is illustrated in (43).

(43) a. [CP hat ... [ [PredP ein Haus [FIP bauen [VP wollen]]].

b. [CP hat... [ [VP wollen] $\left[_{\mathrm{PredP}}\right.$ ein Haus [FIP bauen $\left.\left.\left.t_{\mathrm{VP}}\right]\right]\right]$.

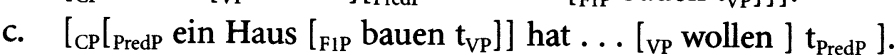

\subsection{VP-Topicalization and extraposed clauses}

The problem at hand is illustrated again in (44). (44) shows that the dependent infinitive can be topicalized together with its CP-complement even though the two categories do not form a constituent after restructuring (44bc). We have already ruled out partial deletion as a solution to our problem and contrary to the case in (43) we cannot resort to further movement of the selecting verb since this movement is restricted to modals and auxiliaries.

(44) a. [zu fragen ob wir zustimmen] wird er versuchen. to ask whether we agree will he try 'He will try to ask whether we agree.'

b. ${ }^{\star}$ Er wird [zu fragen ob wir zustimmen] versuchen. he will to ask whether we agree try

c. Er wird [zu fragen] versuchen [ob wir zustimmen]. he will to ask try whether we agree
Below, we will argue that the solution lies in the way in which CP-complements are licensed. Within a universal base approach one may assume that CP-complements simply remain in the VP (cf. Zwart 1993)), as is indicated in (45). However, from the licensing movement of adjectival small clauses it follows that CP-complements cannnot remain within VP either (46).

(45) a. Ohne zu sagen daß die Maria krank war. without to say that the Maria sick was 'Without saying that Maria was sick.'

b. [CP $\left.\ldots\left[_{\mathrm{FIP}} \mathrm{zu}[\mathrm{VP} \mathrm{V} \mathrm{CP}]\right]\right]$.

(46) a. Ohne froh zu sein, daß der Hans nicht kam. without happy to be that the Hans not came 'Without being happy that Hans did not come.'

b. ${ }^{\star}$ Ohne [froh, daß der Hans nicht kam] zu sein. without happy that the Hans not came to be

c. [CP ohne ... [ [FIP $\mathrm{zu}\left[\mathrm{VP}\right.$ sein $\left[_{\mathrm{Adjp}}\right.$ froh $\left.\left.\left.\left.[\mathrm{CP}]\right]\right]\right]\right]$.

If CP-complements are licensed in situ, then licensing movement of the adjectival predicate will pied-pipe the CP-complement. If deletion of piedpiped material is optional, as we argued above, then we need an extra condition to rule out (46b). This could only be a PF-condition like (47).

(47) A CP-complement may not occur in a cluster of predicates

Since it is not clear what such a condition could be derived from, we will assume licensing movement of the $\mathrm{CP}$ followed by licensing movement of the VP (cf. Koopman and Szabolcsi 2000; Kayne 1998). As is illustrated in (48) first the CP-complement moves out of the VP to be licensed in a functional projection in the middle field, say [SpecF2]. Then the infinitival VP (=F1P) moves to a higher functional position, [SpecF3] in (48). These assumptions will then derive (46a) in the following manner: the CP-complement is extracted before the containing AP is moved to its licencing position in [SpecPredP]

(48) $\left[\mathrm{CP} \ldots\left[\operatorname{Pred}^{0}\left[\left[_{\mathrm{FIP}} \mathrm{zu}[\mathrm{VP} \mathrm{V}]\right]\right.\right.\right.$ F $3\left[_{\mathrm{F} 2 \mathrm{P}} \mathrm{CP}\right.$ F2 [ $\left.\left.\left.\left.\left.\left.{ }_{\mathrm{VP}}\right]\right]\right]\right]\right]\right]$

In verb-complex formation, the infinitival VP may then extract from within F3P (to check its status with the selecting verb) or pied-pipe F3P containing its $\mathrm{CP}$-complement. Which option is taken should follow from economy. If only a feature of the infinitival VP is to be checked, economy forces movement of the minimal structure. If the infinitival VP and its CP-complement share a 
feature, for instance a topic feature, pied-piping, that is, moving a nonminimal structure is allowed since the derivation would otherwise crash on account of an unchecked feature in the CP-complement.

To conclude, we have shown that there are cases of incomplete category dislocation, namely PP-out-of-NP and Discontinuous NPs, that cannot readily be explained in terms of remnant movement and call for an analysis in terms of partial deletion. On the other hand, we showed - given a restrictive theory of deletion - that there are also cases of incomplete category dislocation, namely the cases of conflicting structural requirements that cannot readily be explained in terms of deletion and call for an analysis in terms of remnant movement. It thus follows that both operations can coexist in the grammar. Though both operations yield similar results, they clearly differ in the conditions of their application. Partial deletion occurs when the checking position for the feature of the constituent that may pied-pipe the whole phrase (typically the head and agreeing positions) is closer. Remnant movement occurs. when the checking position for the feature of the constituent that may not pied pipe the whole phrase (typically the complement) is closer, as is illustrated in (49).

(49) a. $\quad \mathrm{F}_{\mathrm{a}} \mathrm{F}_{\mathrm{b}}\left[\mathrm{XP}_{\mathrm{XP}} \mathrm{YP}_{(\mathrm{b})} \mathrm{X}_{(\mathrm{b})} \mathrm{ZP}_{\mathrm{a}}\right] \ldots$ partial deletion

b. $\mathrm{F}_{\mathrm{a}} \mathrm{F}_{\mathrm{b}}\left[\mathrm{XP}_{\mathrm{YP}} \mathrm{YP}_{(\mathrm{a})} \mathrm{X}_{(\mathrm{a})} \mathrm{ZP}_{\mathrm{b}}\right] \ldots$. . remnant movement

\section{Notes}

1. The terms forward deletion (FWD) and backward deletion (BWD) are loaned from the literature on coordination (cf. Wilder (1994)). The operation of FWD targets left-peripheral material in the first conjunct and deletes this material under identity in all conjuncts following. The operation of BWD, in contrast, targets right-peripheral material in the last conjunct and deletes this material under identity in all preceeding conjuncts.

2. An account of (36) in terms of remnant movement is only possible if it is assumed that it is the element 'keiner' and not the complement that is extracted out of the DP. This account thus requires analysing this element not as the head of the DP but rather as the Specifier of a functional projection which takes the NP (or AP) as a complement. Such an analysis not only appears to be unmotivated but is generally untenable since it cannot account for cases like (i).

(i) Bücher hat er nur diese drei gelesen books has he only these three read

\section{References}

Besten, H. den and G. Webelhuth. 1987. "Adjunction and remnant topicalization in the Germanic SOV-languages. Paper presented at the GLOW-Conference, Venice.

Ćavar, D. and G. Fanselow. 1998. Discontinuous Constituents in Slavic and Germanic Languages, ms., University of Hamburg and University of Potsdam.

Chomsky, N. 1995. "Categories and transformations". Chapter 4 in The Minimalist Program. Cambridge MA: THE MIT PRESS Press.

Cinque, G. 1997. Adverbs and Functional Heads: A cross-linguistic perspective. Oxford: OUP. Diesing, M. 1992. Indefinites [Linguistic Inquiry Monograph 20]. Cambridge MA: The MIT Press.

Geilfuß, J. 1990. "Verb- und Verbphrasensyntax". Arbeitspapier Nr. 11 des SFB 340. Tübingen.

Haftka, B. 1991. "Wenn man angeblich soll das Finitum veranstellen müssen". Vortrag Leipzig, Januar 1991.

Haider, H. 1991. "Fakultativ kohärente Infinitivkonstruktionen im Deutschen". Arbeitspapier Nr. 17 des Sonderforschungsbereichts 340. Stuttgart, 1991.

Haider, H. 1995. "Downright down to the right". In On Extraction and Extraposition in German [Linguistics Today 11], U. Lutz and J. Pafel (eds). Amsterdam: John Benjamins.

Hinterhölzl, R. 1997. "CP-licensing, stranded relatives and the nesting requirement on multiple extraposed clauses". Squib, University of Southern California.

Hinterhölzl, R. 1999. "Restructuring Infinitives and the Theory of Complementation, $\mathrm{PhD}$. dissertation, University of Southern California.

Hinterhölzl, R. 2000. "Licensing movement and stranding in the West Germanic OVlanguages". In The Derivation of VO and OV [Linguistics Today 31], P. Svenonius (ed.), 293-326. Amsterdam: John Benjamins.

Kayne, R. 1994. The Antisymmetry of Syntax [Linguistic Inquiry Monograph 25]. Cambridge MA: The MIT Press.

Koopman, H. and A. Szabolcsi. 2000. Verbal Complexes. Cambridge MA: The MIT Press. Müller, G. 1995. "On extraposition and successive cyclicity". In On Extraction and Extraposition in German [Linguistics Today 11], U. Lutz and J. Pafel (eds). Amsterdam: John Benjamins.

Müller, G. 1996. Incomplete Category Fronting. SfS-Report-01-96. Universität Tübingen

Neeleman, A. 1994. Complex Predicates, PhD dissertation, Utrecht University.

Nunez, J. 1995. The Copy Theory of Movement and Linearization of Chains in the Minimalist Program, PhD dissertation, University of Maryland.

Pesetzky, D. 1998. Phrasal Movement and its Kin, ms, MIT.

Truckenbrodt, H. 1995. Extraposition from NP and Prosodic Structure, ms, MIT.

Wilder, C. 1995. "Rightward movement as leftward deletion". In On Extraction and Extraposition in German [Linguistics Today 11], U. Lutz and J. Pafel (eds). Amsterdam: John Benjamins. 
In the series LINGUISTIK AKTUELL/LINGUISTICS TODAY (LA) the following titles have been published thus far, or are scheduled for publication:

35. HRÓARSDÓTTIR, Thorbjörg. Word Order Change in Icelandic. From OV to VO. 2000.

36. GERLACH, Birgit and Janet GRIJZENHOUT (eds.): Clitics in Phonology, Morphology and Syntax. 2000.

37. LUTZ, Uli, Gereon MÜLLER and Arnim von STECHOW (eds.): Wh-Scope Marking. 2000.

38. MEINUNGER, André: Syntactic Aspects of Topic and Comment. 2000.

39. GELDEREN, Elly van: A History of English Reflexive Pronouns. Person, "Self", and Interpretability. 2000.

40. HOEKSEMA, Jack, Hotze RULLMANN, Victor SANCHEZ-VALENCIA and Ton van der WOUDEN (eds.): Perspectives on Negation and Polarity Items. 2001.

41. ZELLER, Jochen : Particle Verbs and Local Domains. 2001.

42. ALEXIADOU, Artemis : Functional Structure in Nominals. Nominalization and ergativity. 2001.

43. FEATHERSTON, Sam: Empty Categories in Sentence Processing. 2001.

44. TAYLAN, Eser E. (ed.): The Verb in Turkish. 2002.

45. ABRAHAM, Werner and C. Jan-Wouter ZWART (eds.): Issues in Formal German(ic) Typology. 2002

46. PANAGIOTIDIS, Phoevos: Pronouns, clitics and Empty Nouns. 'Pronominality' and licensing in syntax. 2002

47. BARBIERS, Sjef, Frits BEUKEMA and Wim van der WURFF (eds.): Modality and its Interaction with the Verbal System. 2002.

48. ALEXIADOU, Artemis, Elena ANAGNOSTOPOULOU, Sjef BARBIERS and Hans Martin GAERTNER (eds.): Dimensions of Movement. From features to remnants 2002.

49. ALEXIADOU, Artemis (ed.): Theoretical Approaches to Universals. n.y.p.

50. STEINBACH, Markus: Middle Voice. A comparative study in the syntax-semantics interface of German 2002.

51. GERLACH, Birgit: Clitics between Syntax and Lexicon n.y.p.

52. SIMON, Horst J. and Heike WIESE (eds.): Pronouns. Grammar and representation n.y.p.

53. ZWART, C. Jan-Wouter and Werner ABRAHAM (eds.): Studies in Comparative Ger manic Syntax. Proceedings from the 15th Workshop on Comparative Germanic Syntax (Groningen, May 26-27, 2000). n.y.p.

54. BAPTISTA, Marlyse (ed.): The Syntax of Cape Verdean Creole. The Sotavento varieties n.y.p.

55. COENE, M. and Yves D'HULST (eds.): From NP to DP. Volume 1: The syntax and semantics of noun phrases. n.y.p.

56. COENE, M. and Yves D'HULST (eds.): From NP to DP. Volume 2: The expression of possession in noun phrases n.y.p.

57. DI SCIULLO, Anna-Maria (ed.): Asymmetry in Grammar. Volume 1: Syntax and semantics. n.y.p.

58. DI SCIULLO, Anna-Maria (ed.): Asymmetry in Grammar. Volume 2: Morphology, phonology, acquisition n.y.p.

59. DEHÉ, Nicole: Particle Verbs in English. Syntax, information structure and intonation n.y.p.

60. TRIPS, Carola: From OV to VO in Early Middle English. n.y.p.

61. SCHWABE, Kerstin and Susanne WINKLER (eds.): The Interfaces. Deriving and interpreting omitted structures. n.y.p. 